\title{
Medievalista
}

\section{Erat simplicis ingenii: A deposição de Garcia da Galiza vista pelos cronistas dos séculos XII e XIII}

Erat simplicis ingenii: The deposition of Garcia of Galiza in the 12th and 13th century Iberian chronicles

\section{Maria Joana Gomes}

\section{(2) OpenEdition}

\section{Journals}

\section{Edição electrónica}

URL: http://journals.openedition.org/medievalista/1602

DOI: 10.4000/medievalista.1602

ISSN: 1646-740X

\section{Editora}

Instituto de Estudos Medievais - FCSH-UNL

\section{Edição impressa}

Data de publição: 1 Janeiro 2018

\section{Refêrencia eletrónica}

Maria Joana Gomes, «Erat simplicis ingenii: A deposição de Garcia da Galiza vista pelos cronistas dos séculos XII e XIII », Medievalista [Online], 23 | 2018, posto online no dia 07 maio 2018, consultado no dia 21 abril 2019. URL : http://journals.openedition.org/medievalista/1602 ; DOI : 10.4000/ medievalista.1602

Este documento foi criado de forma automática no dia 21 Abril 2019.

(C) IEM 


\section{Erat simplicis ingenii: A deposição de Garcia da Galiza vista pelos cronistas dos séculos XII e XIII}

Erat simplicis ingenii: The deposition of Garcia of Galiza in the 12th and 13th century Iberian chronicles

\section{Maria Joana Gomes}

\section{NOTA DO EDITOR}

Data recepção do artigo / Received for publication: 16-03-2017

Data aceitação do artigo / Accepted in revised form: 20-10-2017

Erat simplicis ingenii: A deposição de Garcia da Galiza vista pelos os cronistas dos séculos XII e XIII/ Erat simplicis ingenii: The deposition of Garcia

of Galiza in the $12^{\text {th }}$ and $13^{\text {th }}$ century Iberian chronicles

Maria Joana Gomes

\section{Introdução}

Quando pensamos em deposições régias durante a Idade Média do ocidente peninsular, é a deposição de Sancho II, que teve lugar em 1245, que imediatamente nos ocorre ${ }^{1}$. A recordação deste evento perdurou na memória por se tratar da primeira notícia de destronamento régio no qual se confrontaram vários sectores e figuras da sociedade do reino de Portugal e do vizinho reino de Castela, pelo papel que o Papa Inocêncio III teve na validação do processo, mas também porque o evento encontrou eco e perenidade em várias obras escritas coevas e posteriores, nas quais as perspectivas sobre o sucedido apresentam versões contrastantes. Se nas cantigas de escárnio e mal dizer é visível uma 
crítica acirrada aos alcaides que entregam os castelos de Sancho II ao seu irmão, na historiografia régia portuguesa dos séculos subsequentes nota-se o esgrimir de argumentos em favor do destronamento de Sancho II.

Neste caso em concreto, a produção de discursos antagónicos ou multivariados prende-se directamente com questões de natureza política fundamentais que evocam necessariamente um debate em torno do que define a legitimidade da sucessão régia, das características e qualidades que moldam o conceito de realeza numa determinada época, e do que pode representar quer uma violação dos limites do poder legítimo do monarca, quer uma insuficiência no cumprimento dos seus deveres. Existe, pois, uma relação intrínseca entre a deposição de um rei e a construção de um duplo discurso: por um lado, apologético, procurando sublinhar as qualidades daquele que vem ocupar o lugar do rei deposto; por outro, condenatório, pondo em manifesto os defeitos e procedimentos negativos do rei caído. Poderíamos dizer que, tal como qualquer evento histórico tido como problemático, o destronamento régio é quase indissociável da produção de discurso justificativo desse mesmo evento ${ }^{2}$.

3 Se a deposição de Sancho II de Portugal é sobejamente conhecida, há, no entanto, outros casos documentados na historiografia medieval peninsular que, muito embora não sigam os moldes protocolares aplicados ao destronamento de Sancho II, acabam por ter igual desfecho: o afastamento de um rei do trono e do governo do reino. Um exemplo paradigmático que se tratará neste artigo é o de Garcia II, rei da Galiza entre 1067 e 1072, ano em que foi feito prisioneiro por um dos seus irmãos, Afonso VI de Leão ou Sancho II de Castela, consoante as versões. Os eventos que conduziram a este desenlace são sobejamente conhecidos. Sabe-se que o filho mais novo de Fernando I e de Sancha de Leão, senhores de um vasto território que compreendia Leão, Castela e as Astúrias, e ainda a Galiza e o futuro condado portucalense, veio a ser contemplado com estes dois territórios na famosa divisão dos reinos executada por Fernando I ${ }^{3}$. Aos seus irmãos mais velhos, Sancho e Afonso, os progenitores atribuíram Castela e Leão, respectivamente. Após a morte de Fernando, em 1065, e de Sancha, em 1067, os três irmãos envolvem-se num conflito que originou a morte a Sancho II às portas de Zamora e a captura e prisão de Garcia. $O$ irmão vitorioso, Afonso, acabou por congregar em si a autoridade sobre os três reinos previamente divididos, repondo a unidade territorial do tempo dos seus pais ${ }^{4}$.

Na senda do que se tem vindo a expor, faremos um estudo dos argumentos evocados para justificar (ou não) o destronamento de Garcia da Galiza nos textos historiográficos redigidos no ocidente peninsular nos séculos XII e XIII. Não pretendemos, portanto, chegar a uma reconstrução histórica e fidedigna dos eventos que conduziram à deposição de Garcia ${ }^{5}$. Nem procuramos tão pouco, como fez quase há um século George Tyler Northup, investigar a potencial origem épica e oral desta estória e a sua relação com os textos historiográficos ${ }^{6}$. Partindo do princípio de que a deposição de Garcia constitui o que Angus Ward chamou "a locus of historiographical intervention" que, pelo seu potencial problemático, é objecto de alterações sucessivas por parte dos cronistas, centraremos a nossa atenção na análise ideológica das semelhanças e diferenças da estória de Garcia nos textos historiográficos produzidos no ocidente peninsular durante os séculos XII e XIII para tentarmos perceber de que modo a construção discursiva do episódio se relaciona com o sistema de valores políticos que caracteriza estas crónicas, sobretudo no que diz respeito ao exercício da função régia ${ }^{8}$. Pese embora o facto de esta questão estar intimamente ligada a todo o relato da partição dos reinos, vamos restringir a nossa reflexão à argumentação e às estratégias discursivas 
utilizadas por cada texto para construir a sua versão da deposição do filho mais novo de Fernando I e Sancha de Leão.

\section{A figura de Garcia da Galiza nos textos do século XII}

Os textos historiográficos medievais que abordaram a sucessão dos três filhos de Fernando I e Sancha de Leão, Sancho II de Castela, Afonso VI de Leão e Garcia II da Galiza, deixaram-nos sobre esta última figura muito pouca informação. Como bem apontou Ermelindo Portela, a verdade é que a construção historiográfica do destronamento de Garcia é feita de contradições e omissões, oscilando sempre entre um silêncio eloquente e uma condenação explícita do seu comportamento enquanto rei ${ }^{9}$. Paradoxalmente, a ausência de um discurso sobre o destino trágico deste rei neste período, faz-se sentir com maior intensidade nas terras que teriam estado sob a sua jurisdição: a Galiza e Portugal. De facto, é revelador o silêncio de alguns dos textos produzidos no scriptorium eclesiástico mais importante do território galego - a diocese de Santiago de Compostela - fazem relativamente a esta matéria. Esta diocese galega, respaldada pela tutela do túmulo de Santiago e por uma série de privilégios papais, torna-se, ao longo do século XII, numa das mais importantes da Península Ibérica; e os textos nela produzidos, quer se tratem de cartulários ou de textos historiográficos, mostram a relação de proximidade que esta mantinha com realeza astur-leonesa, ainda que essa relação nem sempre tenha sido cordial $^{10}$. Contudo, Garcia não parece ter colhido grande simpatia junto dos clérigos compostelanos, já que apesar de ser mencionado no Chronicon Compostellanum, nunca o é na Historia Compostellana nem no cartulário conhecido como Tumbo $A^{11}$. No território português, a situação é algo similar. Encontramos uma alusão isolada ao rei Garcia na tradição analística no Chronicon Lusitanum: aqui é referida a sua vitória sobre o conde de Portucale, Nuno Mendes ${ }^{12}$. Mas, no que diz respeito ao final do seu reinado, os textos redigidos em território português são omissos ${ }^{13}$.

Contrariamente às crónicas redigidas no extremo ocidente da Península Ibérica, os textos produzidos em Leão e Castela no período em causa centram-se quase exclusivamente na narração dos eventos que conduziram à prisão e afastamento de Garcia do trono da Galiza. Todos os textos que mencionam a deposição situam-na na sequência narrativa que ficou conhecida como a Partição dos Reinos, e que descrevemos sucintamente algumas linhas acima. Este episódio da divisão territorial empreendida por Fernando I apresenta variações significativas na tradição historiográfica medieval e tardo-medieval que permitem entrever as posições ideológicas dos seus redactores não só relativamente à sucessão de Fernando $\mathrm{I}$, mas também à questão da sucessão régia em geral ${ }^{14}$. Sobre o final abrupto do reinado de Garcia em 1072, verifica-se o mesmo tipo de fenómeno: o câmbio dinástico anómalo que ocorre na sequência da captura e prisão de Garcia é usado pelos redactores dos textos que o mencionam como exemplo ideal para tecer considerações sobre o contexto e invocar argumentos que possam justificar satisfatoriamente o ocorrido.

7 A primeira referência textual à prisão do mais novo dos filhos de Fernando I e Sancha tem origem em Castela. Trata-se de uma curta apostilha inserida no Liber Commicus, um lecionário pertencente ao mosteiro de São Domingo de Silos, próximo de Burgos, e elaborado antes de $1067^{15}$. Neste pequeno relato, narra-se a estória dos conflitos entre os irmãos Sancho, Afonso e Garcia. Este é expulso da Galiza por Sancho II, sendo por ele aprisionado em Burgos. Esta acção de Sancho contra o seu irmão mais novo ocorre na 
sequência de um engano ou de uma ofensa que Garcia teria perpetrado contra o rei de Castela $^{16}$. O mesmo procedimento é repetido em relação a Afonso, que é aprisionado e enviado para o exílio.

8 Se deixarmos de lado as informações que a Postilha Anónima de Silos nos dá a respeito de Afonso VI, que vão também no sentido de justificar a guerra que Sancho II move contra ele $^{17}$, pode dizer-se que, neste sintético relato, se destacam dois elementos que constituem o núcleo do enredo: por um lado, Sancho é apresentado como a figura que dá início aos conflitos armados que terminam com a expulsão e aprisionamento dos seus irmãos, Afonso e Garcia. Por outro, se é verdade que a agressão militar é imputada a Sancho, esse acto é justificado pela pré-existência de uma ofensa ou engano (ob fraudem) de Garcia contra o seu irmão mais velho ${ }^{18}$. A Historia Legionensis, escrita no mosteiro de Santo Isidoro de Leão ${ }^{19}$, provavelmente entre os anos de 1120 e $1135^{20}$, apresenta importantes diferenças relativamente ao texto que acabamos de mencionar. Concebida com o propósito de louvar os feitos de Afonso VI, esta crónica constrói um enredo elaborado dos conflitos em que se envolveram os filhos de Fernando I, entrecruzando a narração dos eventos com comentários pontuais do autor sobre a inevitabilidade dos conflitos entre reis que partilham a função régia ${ }^{21}$.

Neste texto leonês é introduzida uma variante sobre o exílio dos dois irmãos derrotados por Sancho II, ao revelar-se o local para onde Afonso foi enviado: Toledo. E, discrepância ainda mais importante, a Historia Legionensis imputa a captura e prisão de Garcia não a Sancho II, mas a Afonso VI, que segue o conselho da sua irmã Urraca nesta matéria. À primeira vista, a opção do redactor da Legionensis pode parecer paradoxal, já que, sendo Afonso VI objecto de louvor incondicional, torná-lo o captor do seu irmão parece manchar a construção idealizada do protagonista do relato. Contudo, apesar de referir este acto, o texto evoca razões de monta para desculpabilizar o comportamento do rei de Leão: a segurança pessoal de ambos e a protecção do reino ${ }^{22}$. Para além disso, e de forma a reforça ainda mais a benignidade das opções de Afonso VI, a Historia Legionensis avança a ideia de que Garcia não perde o seu estatuto régio, sendo até confirmado como potencial herdeiro do irmão ${ }^{23}$. Toda esta argumentação faz sentido se tivermos presente que a rejeição da divisão da função régia e da divisão territorial é uma das preocupações centrais do texto, como tivemos ocasião de mostrar recentemente ${ }^{24}$. Ainda assim, a alusão à prisão de Garcia por Afonso só se compreende se admitirmos a existência de outras versões do mesmo evento nas quais as acções de Afonso VI não estariam tão bem defendidas, ou seriam mesmo atacadas. É desta linha que se aproxima o Chronicon Compostellanum $^{25}$. Redigido, entre 1126 e $1135^{26}$, provavelmente em contexto compostelano, este breve relato é sobretudo conhecido pelo carácter anti-goticista (o que tem levado os investigadores a entendê-lo como um libelo em defesa dos interesses da diocese de Compostela ${ }^{27}$ ) e pelas acusações que faz contra a rainha Urraca, filha de Afonso VI.

10 Tal como faz a Historia Legionensis, o Chronicon Compostellanum aceita a responsabilidade de Sancho no início dos conflitos e no subsequente exílio de Afonso VI e Garcia ${ }^{28}$. Da mesma forma, atribui a Afonso, guiado pelo conselho de Urraca, a captura e prisão de Garcia, que também coloca já depois da morte de Sancho II em Zamora e logo após o regresso de Afonso do exílio. Ao contrário da Apostilha de Silos e da Historia Legionensis, o Chronicon não elabora nenhuma justificação para a acção ${ }^{29}$. Dado que faz um elogio rasgado a Afonso VI um pouco mais adiante na narrativa ${ }^{30}$, não parece plausível que o Chronicon Compostellanum pretendesse traçar um negro retrato do rei de Leão ao incluir esta 
informação sobre o destino de Garcia. No entanto, é possível que esta alusão tenha sido assim entendida: tendo em conta que o Chronicon Compostellanum parece dialogar muito de perto com a Historia Legionensis ${ }^{31}$, não é difícil aceitar que a versão do Chronicon possa ter contribuído para que a Legionensis se visse na necessidade de arquitectar uma argumentação com vista a desculpabilizar o procedimento de Afonso VI para com o seu irmão mais novo.

11 A versão do episódio proposta pela Chronica Pelagiana $^{32}$, uma crónica dinástica redigida por Pelaio, bispo de Oviedo, depois de $1130^{33}$, é algo diferente. Aqui, o episódio da prisão de Garcia apresenta uma combinação dos motivos presentes nos textos já mencionados: na senda da Historia Legionensis e do Chronicon Compostellanum, a captura de Garcia é apresentada como obra de Afonso. Contudo, a Chronica Pelagiana introduz neste ponto o motivo do engano/engodo, de forma a aclarar as circunstâncias em que essa captura se torna possível: Afonso consegue o seu intento graue ingenium sine pugna ${ }^{34}$.

Entre os textos latinos do século XII, importa ainda ter em conta a Chronica Naierensis ${ }^{35}$. Redigida no mosteiro de Santa Maria la Real de Nájera entre 1173 e $1190^{36}$, esta crónica tem a particularidade de propor uma translatio dos preceitos políticos do goticismo legitimador da dinastia astur-leonesa para a dinastia castelhana ${ }^{37}$. No episódio da deposição de Garcia, a Chronica Naierensis vai, tal como a Apostilha Anónima de Silos, atribuir a prisão de Garcia a Sancho, uma figura que o texto denigre ao longo de todo o relato ${ }^{38}$. Na senda do Chronicon Compostellanum e da Chronica Pelagiana, também recorre ao motivo do engano, mas exprime-o através de outro vocábulo (dolus) ${ }^{39} \mathrm{e}$ ao qual adiciona a alusão ao desconhecimento de Garcia do estratagema planeado pelo irmão (doli nescius). Acorre assim por obrigação (obsequiosus) ao encontro do irmão em Santarém (Sanctum Yreneum), acabando por ser preso e levado para Castela, onde vem a falecer mais tarde ${ }^{40}$.

Como mostrou Francisco Bautista, o autor da Naierensis inova relativamente aos textos que conhecia e que forneciam versões distintas sobre este evento: estabelece uma relação entre o motivo do engano e a figura de Sancho II, ao mesmo tempo que absolve Afonso VI, figura que interessa exaltar, desse comportamento ${ }^{41}$. Para além disso, refere-se a Garcia como "obsequiosus". Este adjectivo pode ter o sentido geral de deferente ${ }^{42}$, mas está relacionado com obsequium, um termo multifacetado, ligado a modos de subordinação política e social, como o serviço feudo-vassálico ${ }^{43}$. Deve pressupor-se que a introdução de tal adjectivo na Chronica Naierensis significa que Garcia estaria politicamente subordinado ao irmão? Ou que apenas indica a vontade de Garcia em cumprir a sua parte no encontro combinado? Por razões que abordaremos mais adiante ${ }^{44}$, inclinamo-nos para a primeira interpretação.

Em suma, as crónicas do século XII relatam a prisão e consequente deposição de Garcia com alguma heterogeneidade. Contudo, é possível agrupar os relatos mencionados em dois tipos: 1) um, mais vinculado ao espaço castelhano, atribui a Sancho a autoria da prisão (Postilha Anónima de Silos e Chronica Naierensis): 2) o outro, presente em textos de procedência leonesa, apresenta este acto como tendo sido praticado por Afonso, com ou sem conselho da irmã de ambos, Urraca (Historia Legionensis, Chronica Pelagiana e Chronicon Compostellanum). Além disso, os textos empregam estratégias para contextualizar ou explicar o evento. Uma, gira em torno do motivo - oscilante, é certo - do engodo: ingenium (no sentido de estratagema), fraus (fraude, logro), dolus (armadilha, engano) ${ }^{45}$. Este motivo surge em todos os textos castelhanos e também na Chronica Pelagiana, redigida em Oviedo. A outra justificação, que apenas surge na Historia Legionensis, tem um carácter "político" mais acentuado (aquilo que poderíamos designar anacronicamente 
como "razão de estado"): a prisão de Garcia é acompanhada por considerações sobre formas de sucessão régia (sucessão horizontal na ausência de descendentes directos) e pela alusão à preservação do seu estatuto régio. Pode, então, dizer-se que, com excepção da Historia Legionensis, que debate a questão a partir de um ponto de vista mais institucional, estas crónicas apresentam uma versão do episódio em que a captura e prisão de Garcia é obtida através de uma aç̧ão dissimulada (Fig. 1).

\begin{tabular}{|c|c|c|c|c|}
\hline Responsável pela & Sancho II de Castela & \multicolumn{3}{|c|}{ Afonso VI de Leão (c/ consilium Urraca) } \\
\hline \multirow[b]{2}{*}{$\begin{array}{c}\text { Argumento } \\
\text { justificativo e/ou } \\
\text { contextualizador } \\
\text { (texto) }\end{array}$} & \multicolumn{2}{|c|}{ Motivo do engano } & Pressa & "Razão de estado" \\
\hline & \multicolumn{2}{|c|}{$\begin{array}{c}\begin{array}{l}\text { Ob fraudem Garsiae } \\
\text { (Apostilla Silos) }\end{array} \\
\text { Doli nesciuset obsequiosus } \\
\text { (Naierensis) } \\
\text { Per ingenium graue, sine pugna } \\
\text { (Pelagiana) }\end{array}$} & $\begin{array}{l}\text { "cum magna } \\
\text { festinatione" } \\
\text { Compostellanum }\end{array}$ & 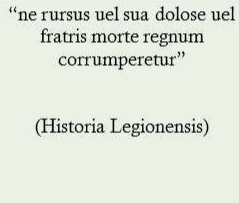 \\
\hline Origem & Castela & Astúrias & Galiza & Leão \\
\hline
\end{tabular}

Fig. 1 - A prisão de Garcia de acordo com a historiografia do século XII (Maria Joana Gomes)

\section{A historiografia do século XIII}

Passemos agora aos textos que mais directamente nos interessam. O primeiro deles, o Chronicon Mundi ${ }^{46}$, foi redigido entre os anos de 1230 e $1236^{47}$. O seu autor, Lucas, também conhecido como Tudense, foi monge do mosteiro de Santo Isidoro de Leão e, posteriormente, bispo de Tui ${ }^{48}$. Para além desta obra historiográfica, deixou outros textos, nomeadamente uma colecção hagiográfica conhecida como Miracula Sancti Isidori e uma obra teológica denominada De altera vita ${ }^{49}$.

O opus magnum do bispo de Tui constitui um relato global da história do mundo que começa com o início da criação e se estende até aos acontecimentos coevos de escrita, terminando com a conquista de Córdova por Fernando III, ocorrida em 1236. Como amiúde sucedia com as obras historiográficas medievais, também é moldado por um príncipio didático e exemplarístico. No entanto, a componente pedagógica nesta obra do Tudense é particularmente acentuada já que, de acordo com o seu próprio prefácio, foi concebida a mando da rainha Berengária como um instrumento para a educação dos seus filhos, sobretudo de Fernando III $^{50}$. O episódio da prisão de Garcia ocorre no quarto e último livro do Chronicon, onde se relatam os acontecimentos compreendidos entre o reinado de Pelaio e a conquista de Córdova, e onde se inscreve a matéria relativa à Partição dos reinos. Para a construção deste segmento do seu texto, o Tudense usou como fonte estrutural a Historia Legionensis, cujo conteúdo enriqueceu com informações provenientes de outros relatos ${ }^{51}$. 
17 Contudo, Lucas de Tui não se limita a copiar a informação contida nesses escritos, procedendo a uma reescrita que inclui remodelações, alterações, cortes, e outro tipo de intervenções ${ }^{52}$. Pode dizer-se que, de um modo geral, as narrativas do bispo de Tui se tornam mais complexas e prolixas do que as que conheceu. Tal deve-se ao facto de o autor combinar várias fontes que apresentam, muitas vezes, versões distintas do mesmo evento, mas também a uma leitura própria dos textos que recebe. É o que sucede na sua versão da deposição de Garcia. Segundo a Legionensis, a prisão do rei da Galiza tinha sido ordenada por Afonso VI ${ }^{53}$. Mas na Chronica Naierensis, que o bispo de Tui também conheceu ${ }^{54}$, Garcia era primeiro exilado por Sancho, tendo depois sido enganado e preso por ele ${ }^{55}$. 0 Chronicon Mundi combina estes dois relatos: aceita que Garcia é primeiro capturado por Sancho e interpreta o adjectivo obsequiosus da Chronica Naierensis na sua dimensão feudovassálica, pois diz que o rei da Galiza acaba por ser libertado pelo irmão mais velho depois de lhe prestar juramento de fidelidade ${ }^{56}$.

18 A partir daqui, e sem deixar de fazer algumas inovações, o Chronicon Mundi retoma a estrutura narrativa da Historia Legionensis, relatando o episódio da morte de Sancho em Zamora, o regresso de Afonso VI do exílio toledano e a nova prisão de Garcia, desta feita por Afonso VI ${ }^{57}$. Neste ponto, o Chronicon Mundi volta a afastar-se da Historia Legionensis, preferindo fornecer uma explicação para a prisão de Garcia diferente da proposta por esta crónica leonesa. O Tudense opta por justificar o sucedido associando a captura de Garcia a dois traços do seu carácter: a ira, que o assalta ao ver-se preterido pelos seus cavaleiros em favor de Afonso VI, e o simplex ingenium, que o impede de se precaver devidamente antes de ir ao encontro do seu irmão para celebrarem a paz ${ }^{58}$.

19 Como interpretar as alterações efectuadas pelo Tudense a este episódio? No que diz respeito à técnica narrativa em questão, podemos pôr a hipótese de se tratar de um caso de recepção activa, em que o autor ressemantiza um dado colhido noutros textos, neste caso em particular, a Chronica Naierensis. Recordamos que este texto atribuía o destino infeliz de Garcia a um desconhecimento do logro concebido pelo seu irmão Afonso (dolo nescius). Ora é possível pensar que Lucas de Tui, conhecendo a versão naierensis, faz já dela uma interpretação que acarreta um juízo de valor negativo relativamente à informação que recebe do cronista asturiano a propósito do encontro de Garcia com Afonso. Se o primeiro, movido pela raiva e ignorando o perigo que o espreita ao encontrar-se com o irmão, não toma precauções antes desse encontro, então Garcia é dotado de uma pobre capacidade de discernimento, simplex ingenium ${ }^{59}$. A reescrita deste episódio por Lucas de Tui assenta num subtil processo de releitura de vocábulos que se prestam a múltiplas interpretações, resultando na transferência da responsabilidade do evento relatado de Afonso VI para Garcia. Através desta subtileza, o cronista desvia a atenção do acto de deslealdade cometido por Afonso VI (dolus) para a imprevidência e ignorância de Garcia ( simplex ingenium).

20 É, portanto, evidente que, face à tradição historiográfica que tem a montante, Lucas de Tui aposta num tipo diferente de argumentação para explicar a deposição de Garcia. Contudo, essas alterações só podem ser cabalmente entendidas quando contextualizadas no âmbito mais alargado das concepções político-sociais que enformam a obra do cronista de Santo Isidoro, e que estão intimamente ligadas quer ao modelo de realeza que defende, quer à sua inequívoca parcialidade a favor de Leão e dos seus monarcas ${ }^{60}$. 0 prológo do Chronicon Mundi permite entrever algumas dessas concepções. Amplamente influenciado por Isidoro de Sevilha ${ }^{61}$, a cujas obras recorreu amiúde, Lucas de Tui manifesta uma visão da realeza onde se valoriza a importância da fé cristã, da justiça e da misericórdia para a 
boa governação ${ }^{62}$, deplorando, ao mesmo tempo, a violência e o belicismo desenfreados, características que, na sua óptica, acabam por ser prejudiciais para o reino por gerarem conflitos desnecessários e desviarem energias do combate ao inimigo da fé ${ }^{63}$. Assim, o Tudense louva, acima de tudo, as virtudes próprias de uma visão clerical e cristã do exercício do poder, concedendo ainda uma importância basilar à sabedoria (sapientia) e à temperança (temperantia) $)^{64}$, ao mesmo tempo que censura a violência desmesurada, que considera própria de um grupo social específico: a aristocracia ${ }^{65}$. Ora Garcia é precisamente apresentado como um rei que exibe a falta destas duas qualidades: movido pela ira, é incapaz de assegurar a fidelidade dos seus súbditos; pouco inteligente, não sabe sequer guardar a sua pessoa do perigo. Em franco contraste com esta figura cheia de defeitos, está Afonso VI, descrito como um rei prudente e sábio, que sabe manter a paz entre todos ${ }^{66}$

21 A reescrita deste episódio por Lucas de Tui tem, sem dúvida, o objectivo imediato de desresponsabilizar Afonso VI do acto cometido contra o seu irmão mais novo. Contudo, tendo em conta os propósitos didáticos do Chronicon Mundi já referidos, podemos assumir que Afonso e Garcia transcendem a sua individualidade e representam, antes de mais, dois modelos antagónicos de realeza: Afonso é apresentado como um rei ideal; Garcia é caracterizado com defeitos que o tornam passível de ser encaixado no protótipo do rex inutilis ${ }^{67}$.

\section{De Rebus Hispaniae}

Poucos anos depois de Lucas de Tui terminar o Chronicon Mundi, mais concretamente em 1243, uma nova crónica foi completada. Sugestivamente intitulada De Rebus Hispaniae ${ }^{68}$, este texto já não tem o perfil de uma crónica universal como o Chronicon de Lucas de Tui, mas sim o da história de um território, a Espanha, e daqueles que o dominaram ${ }^{69}$. 0 seu autor foi Rodrigo Ximénez de Rada ${ }^{70}$, magnata de origem navarra e arcebispo de Toledo.

Este texto, que tem como objectivo central a exaltação Castela (e a defesa da primazia de Toledo sobre as restantes dioceses peninsulares), mantém uma relação textual próxima com o Chronicon Mundi de Lucas de Tui, que usou como fonte ${ }^{71}$. Apesar disso, as duas obras espelham as diferenças de posição dos seus autores no que concerne às respectivas concepções político-sociais ${ }^{72}$. Essas divergências estão também patentes no episódio aqui nos ocupa, a deposição de Garcia. O afastamento de posições dos dois cronistas é logo visível nos prólogos que antecedem a matéria narrativa de cada uma das crónicas. Do princípio didático explícito formulado pelo Tudense, o Toledano passa ao louvor exemplarístico dos feitos dos homens do passado ${ }^{73}$ : o Tudense pretendia ensinar o rei a agir, Rodrigo de Rada pretende celebrar um rei que age de acordo com determinados preceitos.

Rodrigo de Rada concebe o exercício do poder na sociedade como o resultado de uma relação dialógica entre grupos sociais, destacando a aristocracia, cujo papel político, embora diferente do do monarca, considera igualmente importante ${ }^{74}$. Nesta relação simbiótica que se estabelece entre o monarca e os aristocratas, cada parte detém os seus direitos e deveres, e é sobre o compromisso pessoal de cumprimento das obrigações mútuas que assenta o edifício político arquitectado pelo Toledano ${ }^{75}$. Associadas ao cumprimento (ou não) deste pressuposto estão certo tipo de qualidades, simultaneamente individuais (porque se materializam ou não num indivíduo) e colectivas (comuns a todo o 
grupo social). Assim, a importância que o grupo nobiliárquico (sobretudo o castelhano) adquire no Toledano vai reflectir-se no modo como este cronista modela a figura idealizada do monarca. Do mesmo modo, o apreço que Rodrigo de Rada manifesta por este grupo social implica uma definição das qualidades paradigmáticas dos seus membros. Vejamos em que termos são definidos um e outros.

O monarca ideal deverá possuir várias virtudes. Se no Tudense se destacavam a sapiência, o Toledano considera como virtude essencial ao exercício do poder soberano a larguitas, isto é, a capacidade de reconhecer e recompensar o contributo da aristocracia para a existência e prosperidade do reino, e ainda a strenuitas e justitia, qualidades que permitem o estabelecimento e a manutenção de uma relação social harmoniosa ${ }^{76}$. Por seu lado, na aristocracia, Rodrigo de Rada valoriza a lealdade (fidelitas) ${ }^{77}$. Neste particular, a questão da territorialidade adquire no Toledano uma dimensão importante pois acarreta o reconhecimento da aristocracia como elemento mediador entre o rei e um determinado território. Essa concepção implica um desdobramento do objecto da fidelitas aristocrática: ela pode resultar do estabelecimento de um vínculo pessoal e volitivo com um monarca ou outra figura que representa uma autoridade (fidelitas contratual), ou então ser parte integrante da relação de um determinado homem com a terra de onde é natural e, consequentemente, do senhor que a governa (fidelitas natural). Não raras vezes, estes dois tipos de fidelidade entram em conflito ${ }^{78}$. Ora, a nosso ver, a versão da deposição de Garcia da Galiza contada no De Rebus Hispaniae não só está moldada pelos princípios que acabámos de elencar, como parece constituir-se como uma estória exemplar que concretiza - confirmando, por isso, o propósito didático da história - os princípios teóricos enunciados pelo arcebispo de Toledo.

o Chronicon Mundi leva a narrativa da deposição de Garcia por um caminho diferente do dos textos do século XII. Reformula de tal forma o motivo do engodo de que Garcia fora vítima que, de estratagema para o afastamento do rei da Galiza do trono, acaba por ser transformado não numa armadilha, mas num defeito do próprio Garcia, que denotava a sua incapacidade para a governação e que, portanto, fazia cair o rei da Galiza no paradigma do rex inutilis ${ }^{79}$. Já no De Rebus Hispaniae, a correlação entre a deposição do filho mais novo de Fernando I e Sancha de Leão e sua incompatibilidade com o regimento do reino vai ser veiculada de outro modo: através da acusação de tirania. Na sequência da partida de Afonso para o exílio e da tomada de Leão por Sancho, o De Rebus Hispaniae dá conta da situação política no reino da Galiza. Garcia, confrontado com a proximidade de Sancho, tenta atacá-lo ao mesmo tempo que se envolve em perseguições contra os seus súbditos, que o De Rebus considera serem tirânicas (tirannide) ${ }^{80}$. Essa terrível acusação é seguida por um episódio novo onde o Toledano mostra o comportamento do rei da Galiza com os aristocratas que senhoreia.

Garcia mantém junto a si um conselheiro de baixo nível social (vermulus) que difama constantemente os magnates da sua corte. Apesar dos reiterados pedidos dos senhores lesados para que afaste de si este mau conselheiro, Garcia recusa livrar-se dele ${ }^{81}$. Confrontados com esta resposta insatisfatória, os cavaleiros decidem agir e matam o conselheiro na presença do rei. Indignado, Garcia começa a perseguir indiscriminadamente os seus vassalos que, perante a atitude do seu senhor, transferem a sua lealdade para Sancho de Castela ${ }^{82}$. 0 abandono dos cavaleiros acaba por ser um factor decisivo para a derrota de Garcia em Santarém e para o seu aprisionamento pelo irmão mais velho. 
28 Na senda do Tudense, mas de forma muito mais explícita, o De Rebus Hispaniae estabelece uma relação entre a deposição de Garcia e o (mau) tratamento que este dá aos seus milites e barones ${ }^{83}$. Ao mesmo tempo, e diferentemente de Lucas de Tui, insere o tópico do mau conselheiro como elemento catalisador da crescente espiral de violência. Noutros autores, este tópico surge em conjugação com a construção da figura do rex inutilis ${ }^{84}$. Contudo, aqui Garcia não parece ser retratado como um rex inutilis, estando mais próximo do perfil do tirano. Por preferir o conselho de um homem com estatuto social inferior, Garcia acaba por perseguir indiscriminadamente (indistincte) ${ }^{85}$ todos os súbditos, independentemente do seu envolvimento na morte desse conselheiro predilecto. Precisamente por isso, Garcia demonstra ser um rei injusto, não sabe quem recompensar e quem castigar. Ora um rei incapaz de aplicar convenientemente a justiça nos seus reinos não é tanto um rei incapaz, mas um rei que governa de forma tirânica ${ }^{86}$.

O episódio do conselheiro implica, como vimos, a construção de uma nova perspectiva sobre a deposição de Garcia, que se enquadra de forma clara no programa político do Toledano. A deposição do rei da Galiza é avaliada e validada a partir de uma correlação entre a tirania e injustiça do rei para com o grupo nobiliárquico, que ganha assim legitimidade para a quebra da fidelidade natural e para a sua substituição pela fidelidade contratual a um novo senhor, como aliás sucede noutros pontos da narrativa ${ }^{87}$. Portanto, o De Rebus Hispaniae reescreve o episódio da deposição de Garcia à luz da problemática das relações entre realeza e aristocracia, uma das preocupações fundamentais de Rodrigo de Rada.

\section{Conclusão}

30 A análise das estratégias argumentativas dos textos dos cronistas dos séculos XII e XIII usadas para justificar a deposição de Garcia da Galiza permitiu entrever a complexidade e a riqueza dos motivos narrativos e dos pressupostos políticos que se cruzam neste pequeno episódio. Pode dizer-se que ficou patente que a construção argumentativa proposta por cada texto é feita sempre a partir de um diálogo intenso com a tradição textual coeva ou mais antiga. Partindo de uma leitura motivada / tendenciosa de vocábulos específicos, os redactores dos textos reconfiguram determinados motivos de forma a dar-lhe um sentido que se enquadre com a sua visão do mundo e no seu entendimento do poder político e da função régia. De acordo com estes preceitos, a responsabilidade da captura e deposição de Garcia oscila, consoante o aproveitamento e ensinamento político pretendido, entre Sancho e Afonso, entre um castelhano e um leonês.

31 Encontramos algumas diferenças entre a tradição textual dos séculos XII e XIII no que toca à abordagem deste problema. À excepção da Historia Legionensis, que opta por uma argumentação já marcadamente política, os textos do século XII mencionam sem grande detalhe o tipo de acto que propiciou a queda de Garcia. Neste aspecto, todos os textos recordam, através de uma terminologia reveladora, o motivo do engano, o que pode sugerir que a estória veiculada absorveu outras tradições mais arcaicas, uma hipótese que não nos foi possível explorar.

32 A construção do mesmo episódio pelos cronistas do século XIII reveste-se de outros processos. Quer o Tudense quer o Toledano procuram encontrar para a deposição de Garcia da Galiza uma explicação que vá para além da mera desresponsabilização do seu 
irmão, Afonso VI. O destronamento do filho mais novo de Fernando I e Sancha de Leão é aproveitado pelos dois cronistas para tecer, dentro do seu quadro ideológico e da sua visão do poder, um exemplo negativo de realeza. O Tudense, prezando virtudes como a sapientia, fá-lo imputando a Garcia uma candura ou uma falta de inteligência que o desqualifica como bom rei. Por seu lado, o Toledano, recuperando o tema dos maus conselheiros, condena em Garcia a incapacidade de fazer justiça e de exercer a boa governação com o consilium dos nobres. Assim, os cronistas do século XIII utilizam este episódio para fornecer um exemplo concreto e negativo das suas teorias políticas sobre a função régia. Lucas de Tui constrói uma imagem de Garcia mais próxima do paradigma do rex inutilis. Rodrigo de Toledo, encena-o como um tirano. Num caso como no outro, o destino historiográfico de Garcia da Galiza não foi mais misericordioso do que a sua vida.

\section{BIBLIOGRAFIA}

Fontes

CARMEN Campidoctoris. Ed. Emma Falque Rey, Juan Gil y Antonio Maya, Historia Roderici vel gesta Roderici Campidocti. Corpus Christianorum Continuatio Medievalis (Chronica Hispana saeculi XII. Pars I), vol. 71. Turnhout: Brepols, 1990.

CHRONICA Legionensis (olim silensis). Ed. Justo Pérez de Urbel y Atilano González Ruiz-Zorrilla. Madrid: Ruiz-Zorrilla, 1959.

CHRONICA Naierensis. Ed. Juan Estévez Sola. Corpus Christianorum Continuatio Medievalis (Chronica Hispana saeculi XII, Pars II), vol. 71A. Turnhout: Brepols, 1995.

CHRONICA Najerense. Ed. e trad. espanhola Juan A. Estévez Sola. Madrid: Akal, 2003.

CHRONICON Compostellanum. Ed. Emma Falque. Habis 14. Sevilla: Publicaciones de la Universidad de Sevilla, 1983, pp. 73-83.

CHRONICON Lusitanum (Chronica Gothorum). “Annales Portucalenses Veteres”. Ed. Pierre David. in: DAVID, Pierre - Études Historiques sur La Galice et le Portugal du VIe au XIIe siècle. Coimbra: Instituto de Estudos Históricos Dr. António de Vasconcelos, 1947, pp. 291-302.

HISTORIA Roderici vel gesta Roderici Campidocti. Ed. Emma Falque Rey, Juan Gil y Antonio Maya. Corpus Christianorum Continuatio Medievalis, vol. 71 (Chronica Hispana saeculi XII. Pars I). Turnhout: Brepols, 1990.

JUAN DE OSMA - Crónica latina de los reyes de Castilla. Ed. e trad. espanhola Luis Charlo Brea. Madrid: Akal, 1999.

LUCAS DE TUI - Chronicon Mundi. Ed. Emma Falque. Corpus Christianorum Continuatio Medievalis, vol. 74. Turnholt: Brepols, 2003.

PELAIO DE OVIEDO - Crónica del Obispo don Pelayo. Ed. Benito Sánchez Alonso. Madrid: Centro de Estudios Históricos, Imprenta de los sucesores de Hernando, 1924.

RODRIGO XIMÉNEZ de RADA, arcebispo de Toledo - Historia de rebus hispaniae sive historia gotica. Ed. Juan Valverde. Corpus Christianorum Continuatio Mediaevalis, vol. 72. Turnhout: Brepols, 1989. 
Estudos

BARTON, Simon; FLETCHER, Richard - The world of el Cid: chronicles of the Spanish reconquest. Manchester: Manchester University Press, 2000.

BAUTISTA, Francisco - "Breve historiografía: Listas regias y Anales en la Península Ibérica (siglos VII-XII)". Talia dixit 4 (2009), pp. 113-190.

BAUTISTA, Francisco - "Sancho II y Rodrigo Campeador en la Chronica Naierensis". e-Spania [em linha] 7 (2009) [Consultado a 20-01-2017]. Disponível em: http://e-spania.revues.org/18101 DOI: 10.4000/e-spania. 18101

ECKEL, Auguste - Charles le Simple. Paris: Éd. Bouillon, 1899.

ESTÉVEZ SOLA, Juan - “Introducción”. in Crónica Najerense. Ed. e tradução espanhola de Juan Estévez Sola, Madrid: Akal, 2004.

FALQUE, Emma - "Introduction”. in LUCAS DE TUI - Chronicon Mundi, Ed. Emma Falque. Corpus Christianorum Continuatio Medievalis, vol. 74. Turnhout: Brepols, 2003, pp. i-lxxxvii.

GLARE, P. G. - Oxford Latin Dictionary. Oxford: Clarendon Press, 1968.

GOMES, Maria Joana - O rei na escrita: as múltiplas faces de Afonso VI (sécs. XI-XII). Porto: Faculdade de Letras da Universidade do Porto, 2017. Tese de Doutoramento.

HENRIET, Patrick - "Sanctissima patria. Points communs entre les trois œuvres de Lucas". in HENRIET, Patrick - Actes du colloque: Chroniqueur, hagiographe, théologien. Lucas de Túy (†1249) dans ses œuvres (Sorbonne-Collège d'Espagne, 10 décembre 1999). Cahiers de linguistique et de civilisation hispaniques médiévales 24 (2001), pp. 249-278.

JEREZ CABRERO, Enrique - El Chronicon Mundi de Lucas de Tuy (C. 1238): Técnicas compositivas y motivaciones ideológicas. Madrid: Facultad de Letras y Filosofía de la Universidad Autónoma de Madrid, 2006. Tese de Doutoramento.

LINEHAN, Peter - "De Lucas de Tui a Alfonso X”. in FERNÁNDEZ-ORDÓNEZ, Inés (org.) - Alfonso X el sabio y la Crónicas de España, Valladolid: Universidad de Valladolid-Centro de Estudios para la Edición de Clásicos Españoles, 2000, pp. 19-36.

MARTIN, Georges - Les Juges de Castile: mentalités et discours historique dans l'Espagne médiévale. Paris: Séminaire d' Études Médiévales Hispaniques, 1992.

MARTIN, Georges - "Nobleza y realeza en el De rebus Hispaniae (Libros 4 a 9)". in MOLINIE, Annie; ZIMMERMANN, Marie-Claire; RALLE, Michel (pres.) - Hommage à Carlos Serrano. Paris: Éditions hispaniques, 2 vols., 2005, pp. 1-23.

MARTIN, Georges - “Ordoño Sisnández, autor de la Historia Legionensis (llamada silensis). Notas histórico-filológicas sobre un ego fundador". e-Spania [em linha] 14 (2012) [Consultado a 22-01-2017]. Disponível em: http://espania.revues.org/21711

DOI: $10.4000 /$ e-spania.21711

MARTIN, Georges - "Toponimia y avidez de los reyes: doble lexicalización de los territorios hispanos en la Historia Legionesis" (llamada Silensis). e-Spania [em linha] 13 (2012) [Consultado a 22-01-2017]. Disponível em: http://espania.revues.org/21070

DOI: $10.4000 /$ e-spania. 17990

MONTANER, Alberto - "Presencia y ausencia de Alfonso VI en la Historia Legionensis (hactenus Silensis nuncupata)". e-Spania [em linha] 14 (2012) [Consultado a 26-02-2017]. Disponível em: http://e-spania.revues.org/21750

DOI: $10.4000 /$ e-spania. 21750 
NIEDERMEYER, J. L. - Mediae Latinitaties Lexicon Minus. Leiden: Brill, 1975.

NORTHUP, George Tyler - “The Imprisionment of King García”. Modern Philology 17 (1919), pp. 393-412.

PÉREZ DE URBEL, Justo - “Introducción”. in Liber Commicus. Edición crítica. Madrid: CSIC, 1955.

PÉREZ RODRÍGUEZ, Estella - "La Historia Roderici en su aspecto léxico: Estudio comparativo en relación con la Chronica Adefonsi Imperatoris y las crónicas hispanolatinas anteriores al siglo XIII". e-Spania [em linha] 15 2013. [Consultado a 25-02-2017]. Disponível em: http://espania.revues.org/22341

DOI: $10.4000 /$ e-spania.22341

PETERS, Edward - The Shadow King: the rex inutilis in Law and literature. New Haven: Yale University Press, 1970.

PORTELA, Ermelindo - García II de Galicia, el rey y el reino (1065-1090). Burgos: La Olmeda, 2001.

RAMOS Y LOSCERTALES, José María - “El reino de Aragón bajo la dinastía pamplonesa”. Acta Salmanticensia tomo XV, 2, 1961.

REGLERO DE LA FUENTE, Carlos - "Omnia totius regni sui monasteria: la Historia Legionense, llamada Silense, y los monasterios de las infantas”. e-Spania [em linha] 14 (2012) [Consultado a 25-02-2017]. Disponível: http://espania.revues.org/21775\#ftn3 DOI: 10.4000/e-spania.21775

RODRÍGUEZ DE LA PEÑA, Manuel Alejandro - "Rex institutor scholarum: la dimensión sapiencial de la realeza en la cronística de León-Castilla y los orígenes de la Universidad de Palencia”. Hispania Sacra 126 (2010), pp. 491-512.

WARD, Aengus - History and Chronicles in Late Medieval Iberia: Representations of Wamba in late medieval narrative histories. Leiden: Brill, 2011.

\section{NOTAS}

1. Sobre a deposição de Sancho II podem ser consultados os seguintes títulos: VARANDAS, José - Bonus Rex ou Rex inutilis: as periferias e o centro (redes de Poder no reinando de D. Sancho II (1223-1248). Lisboa: Faculdade de Letras da Universidade de Lisboa, 2003. Tese de Doutoramento. FERNANDES, Hermenegildo - Sancho II. Colecção dos Reis de Portugal. Lisboa: Círculo de Leitores, 2006; MOREIRA, Filipe - “"E des ally foi pera mall' - o reinado de D. Sancho II na cronística medieval portuguesa”, Revista Diálogos Mediterrânicos 3 (2012), pp. 160-171; MATTOSO, José - “A crise de 1245”. in MATTOSO, José - Portugal medieval: novas interpretações. Obras Completas, 12 vols. Lisboa: Círculo de Leitores, 2002, vol. 8, pp. 47-60; PETERS, Edward - The Shadow King, the Rex inutilis in medieval law and literature (751-1327). New Haven and London: Yale University Press, 1970, pp. 135-170; SANTOS, Herlander Gonçalves dos - D. Sancho II: da deposição à composição das fontes literárias dos séculos XIII e XIV. Porto: Faculdade de Letras da Universidade do Porto, 2009. Dissertação de Mestrado. Disponível em:

https://repositorio-aberto.up.pt/bitstream/10216/20092/2/ mestherlandersantossanchoII000084373.pdf

2. PETERS, Edward - The Shadow King, p. 23.

3. Sobre o episódio conhecido como Partição dos reinos há uma profusa bibliografia. Saliento alguns títulos que se centram estritamente o episódio: MENÉNDEZ PIDAL, Ramón - La España del Cid. 2 vols. Madrid: Espasa-Calpe, 1929; POWELL, Brian - “The "Partición de 
los reinos" in the "Crónica de veinte reyes"'. Bulletin of Hispanic Studies LXI (1984), pp. 459-471; VAQUERO, Mercedes - "El rey don Alfonso, el que dixieron el Bravo e el de las partiçiones”. Boletín de la Real Academia Española 70 (1990), pp. 265-288; CATALÁN, Diego La épica española: nueva documentación y nueva evaluación. Madrid: Fundación Ramón Menéndez Pidal; JARDIN, Jean-Pierre - "La partición de los reinos de Fernando I en la Chronica Naiarensis". e-Spania [em linha] 7 (2009) [Consultado a 20-01-2017]. Disponível em: http://e-spania.revues.org/17991

4. Para uma perspectiva histórica sobre estes acontecimentos veja-se: GAMBRA, Andrés Cancillería, Curia e Imperio: Diplomatario de Afonso VI. León: Centro de Estudios San Isidoro, 1998, vol. 1, pp. 77-100; LINAGE CONDE, Antonio - Alfonso VI: El rey hispano y europeo de las tres religiones. Burgos: La Olmeda, 1994 (reed. 2006); PORTELA, Ermelindo - García II de Galicia, el rey y el reino (1065-1090). Burgos: La Olmeda, 2001; GONZÁLEZ MÍNGUEZ, César - El proyecto político de Sancho de Castilla (1065-1072). Palencia: ITTM, 2002, pp. 77-99; MÍNGUEZ, José María - Alfonso VI: poder, expansión territorial y reorganización interior. Donostia/San Sebastián: Nerea, 2003; FERNÁNDEZ GONZÁLEZ, Etelvina - Alfonso VI y su época. Los horizontes de Europa (1065-1109). León: Instituto Leonés de Cultura, 2009. Para a construção da sua identidade textual veja-se a minha recentemente defendida Tese de Doutoramento: GOMES, Maria Joana - O rei na escrita: As múltiplas faces de Afonso VI (sécs. XI-XII). Porto: Faculdade de Letras da Universidade do Porto, 2017. Tese de Doutoramento.

5. Remeto para o estudo biográfico de Ermelindo Portela acima citado e que aborda esta questão.

6. NORTHUP, George Tyler - "The Imprisionment of King García". Modern Philology 17 (1919), pp. 393-412.

7. WARD, Aengus - History and Chronicles in Late Medieval Iberia: Representations of Wamba in late medieval narrative histories. Leiden: Brill, p. 174.

8. Deixamos de fora de uma abordagem mais exaustiva outro texto historiográfico fundamental redigido no século XIII, a Chronica Regum Castellae. Este texto, escrito pelo chanceler de Fernando III, Juan de Osma entre 1223 e 1239 não faz qualquer referência à captura e prisão de Garcia no contexto dos conflitos entre os filhos de Fernando I, limitando-se a dizer quais as terras recebidas pelo filho mais novo de Fernando e Sancha na divisão dos reinos, atribuindo-lhe erradamente a tutela de Najera e de Navarra e não da Galiza (ver JUAN DE OSMA - Crónica Latina dos reis de Castela. Ed. e trad. Espanhola: Charles Brea, Madrid: Akal, 1999, p. 26). Trata-se de uma confusão entre dois Garcias: o filho de Sancha de Leão e de Fernando I, e o irmão de Fernando I, rei de Navarra e conhecido como "el de Nájera".

9. PORTELA, Ermelindo - García II, pp. 7-14. A escassez de fontes sobre este rei é transversal à sua colecção diplomática. Ainda segundo PORTELA, Ermelindo - García II, p. 176, apenas sete documentos sobrevivem em que Garcia cumpre uma função relevante. É interessante ressalvar que não encontramos qualquer referência a este rei, quer na historiografia, quer na documentação produzidas e/ou conservadas na catedral de Santiago de Compostela no século XII. A documentação de Sancho e Afonso assim como a de Fernando I e das infantas Elvira e Urraca poderão prestar alguns esclarecimentos adicionais sobre a forma como se terá desenrolado o afastamento de Garcia do trono da Galiza.

10. Ver GOMES, Maria Joana - O rei na escrita, sobretudo pp. 151-167 e bibliografia citada. 11. PORTELA, Ermelindo - García II, p. 174, relaciona este silêncio com a restauração da diocese de Braga em 1071. Há, no entanto, alguns documentos de Garcia referidos e 
editados por Ermelindo Portela que estão vinculados a outras instituições eclesiásticas galegas: Lugo (1), Mondonhedo (1), e mosteiro de Toques (1).

12. CHRONICON Lusitanum (Chronica Gothorum). "Annales Portucalenses Veteres". Ed. Pierre David. in: DAVID, Pierre - Études Historiques sur La Galice et le Portugal du VIe au XIIe siècle. Coimbra: Instituto de Estudos Históricos Dr. António de Vasconcelos, 1947, pp. 291-302, p. 298. Dos documentos citados por Ermelindo Portela, a antiga abadia de Pendorada, situada actualmente no concelho de Marco de Canaveses, é a instituição à qual está associado um maior número de documentos de Garcia hoje editados (três), o que leva o investigador galego a afirmar que a memória "portuguesa” de Garcia está preferencialmente vinculada ao território situado entre Douro e Minho (PORTELA, Ermelindo - García II, p. 174), enquanto a zona a sul do Douro parece pautar-se por um silêncio semelhante ao que encontramos nas fontes galegas.

13. Séculos mais tarde, a narrativa da captura e prisão de Garcia será recontada pela Crónica de 1344 de Pedro de Barcelos, que reconfigura e reescreve o episódio tal como o recebera da tradição historiográfica afonsina. 0 tratamento do episódio pelos vários textos e as respectivas interpretações foram já estudadas em DIAS, Isabel de Barros - "Os impossíveis grilhões do futuro". $6^{\circ}$ Congresso da Associação Internacional de Lusitanistas [em linha]. 2001 (texto consultado pela última vez a 18-10-2009, actualmente indisponível).

14. GOMES, Maria Joana - O rei na escrita, pp. 281-289.

15. PÉREZ DE URBEL, Justo - “Introducción”. in Liber Commicus. Edición crítica, Madrid: CSIC, 1955, p. XLV.

16. POSTILLA Anónima de Silos. Ed. Ramón Menéndez Pidal in La España del Cid, vol. II, p. 709: "Rex Sancius prolix Ferdinando, ob fraudem sui fratri Garseani, ira comotus, eum, de Gallecia expulsum et captum in opidum Burgos in exilium trusit".

17. Na mesma linha, o ataque de Sancho contra Afonso VI é justificado pela inveja sentida por este em relação ao primeiro (causa invidia). Esta qualidade, juntamente com a ira, é também evocada em outros textos, como forma de explicar um determinado comportamento menos aceitável. Por exemplo, nos textos cidianos, a ira e inveja de Afonso VI são tidas como justificação para a expulsão do Cid do reino: No Carmen Campidoctoris, a tentativa de inimizar o rei com o Cid deriva da inveja sentida por um grupo anónimo de cavaleiros relativamente ao prestígio do Campeador. A interferência deste grupo de cavaleiros na relação entre o rei e o Cid acaba por despertar a ira do rei que exila o cavaleiro castelhano no Carmen Campidoctoris. A associação entre a inveja e o conflito está também patente noutros textos historiográficos peninsulares: existe o episódio em que Fruela I mata o seu irmão Vímara "ob inuidia" (Chronica Albeldensia e também na Historia Legionensis). Na Historia Legionensis, a inveja é também apresentada como o motivo que mobiliza Garcia III de Navarra contra o seu irmão, Fernando. Esse sentimento é motivado, segundo a crónica, pela magnificência e opulência que rodeiam Fernando I, agora rei de Leão. Apesar de o texto não estabelecer essa ligação, a verdade é que pode perceber-se que a inveja de Garcia é motivada pela subida de Fernando I ao trono leonês, acabando por ultrapassar em estatuto o seu irmão mais velho e primogénito. Se a divisão dos reinos de Sancho III implicava, como se pensa uma prevalência do primogénito sobre os irmãos mais novos, como propõe RAMOS Y LOSCERTALES, José María - "El reino de Aragón bajo la dinastía pamplonesa”. Acta Salmanticensia tomo XV, 2 (1961), pp. 56-58, então a subida ao trono leonês de Fernando I poderia constituir uma ameaça a essa posição de superioridade do seu irmão. Recordemos também que a inveja foi o motivo apresentado por Caim para o assassinato de Abel. 
18. O texto não esclarece qual o tipo de engano cometido. A polissemia da palavra remete, num sentido lato para um engano ou ofensa, e, num sentido mais específico, para o domínio do direito contratual. É possível que o autor anónimo do texto estivesse consciente dessa polissemia. Para além disso, também é necessário dar importância à referência ao exílio presente neste texto, não só pela sua importância simbólica relacionada com a perda da terra, temática que, como sabemos, tinha ampla ressonância na historiografia medieval peninsular, mas também porque esta alusão ao duplo exílio de Garcia e Afonso é matéria narrativa que encontra eco em todos textos historiográficos posteriores, sendo especialmente desenvolvida pela historiografia afonsina e pós-afonsina (Versão Sanchina da Estória de Espanna e Crónica de 1344).

19. A proveniência deste texto foi e é matéria para amplo debate entre os investigadores. Actualmente, as posições dividem-se entre aqueles que se inclinam para o mosteiro de Santo Isidoro de Leão (Gómez Moreno, Simon Barton e Richard Fletcher, George Martin, Hélene Thieulin-Pardo, Gaelle le Morvan) e os que relacionam a redacção desta crónica com o mosteiro de Sahagún (Benito Sánchez-Alonso, Canal Sánchez-Pagín, Peter Linehan e Patrick Henriet). Posta de lado está a hipótese de esta crónica proceder do mosteiro de São Domingos de Silos, como defendiam Ramón Menéndez Pidal, Francisco Santos Coco e Justo Pérez de Urbel.

20. Os investigadores não têm uma posição unânime relativamente à datação do texto. Para Simon Barton e Richard Fletcher a obra foi escrita entre 1109 e 1120 (BARTON, Simon; FLETCHER, Richard - The world of El Cid. Chronicles of the Spanish Reconquest. Manchester: Manchester University Press, 2000, p. 12. Alberto Montaner propõe que o texto tenha sido redigido antes de 1135, data em que Afonso VII passa a reivindicar para si o uso do título imperial (MONTANER, Alberto - "Presencia y ausencia de Alfonso VI en la Historia Legionensis (hactenus Silensis nuncupata)", e-Spania [em linha] 14 (2012), § 21 [consultado a 22-01-2017]. Disponível em: http://e-spania.revues.org/21750. Georges Martin põe a hipótese de o texto ter sido redigido entre os anos de 1121 e 1133, época em que Ordoño Sisnández, que o investigador francês considera como autor do texto, permaneceu em San Isidoro, mas sugerindo também que o terminus ante quem seja o ano de 1153 (MARTIN, George - "Ordoño Sisnández, autor de la Historia Legionensis (llamada Silensis). Notas histórico-filológicas sobre un ego fundador". e-Spania [em linha] 14 (2012), $\S 24$ [Consultado a 22-01-2017]. Disponível em: http://espania.revues.org/21711 21. Para a questão da estrutura da Historia Legionensis ver MONTANER, Alberto "Presencia y ausencia de Alfonso VI". Para uma interpretação e funcionalidade dos comentários do narrador em geral ver MARTIN, Georges - "Ordoño Sisnández". Para a sua funcionalidade no episódio da partição dos reinos ver GOMES, Maria Joana - 0 rei na escrita, sobretudo pp. 278-288.

22. HISTORIA Legionensis. Ed. Justo Pérez de Urbel, p. 123: "Huius itaque Adefonsum acepto consilio [de Urraca] hac scilicet necessitudine anxius, ne rursus uel sua dolose uel fratris morte regnum corrumperetur, Garsiam minimum fratrem cepit".

23. HISTORIA Legionensis. Ed. Pérez de Urbel, p. 125: “[...] cui in vincula presto posito, preter licentiam inperitandi, omnis regis honor exhibebatur. Considerabat namque Adefonsus hunc interim salua pace post se regnaturum sed inperatrix natura que homini ineuitabilem mortis metam infixit, interueniens, sub eadem custoria, multo post febre correptus, obiit".

24. GOMES, Maria Joana - O rei na escrita, pp. 278-288.

25. CHRONICON Compostellanum. Ed. Emma Falque. Habis 14. Sevilla: Publicaciones de la Universidad de Sevilla, 1983, pp. 73-83. 
26. A datação proposta baseia-se na referência à morte de Urraca (1126) e à identificação de Afonso Raimundes como rei e não imperador (MARTIN, Georges - Les Juges de Castille: mentalités et discours historique dans l'Espagne médiévale. Paris: Séminaire d' Etudes Médiévales Hispaniques, 1992, pp. 96-97). Francisco Bautista propôs recentemente uma datação mais tardia (BAUTISTA, Francisco - "Breve historiografía: Listas regias y Anales en la Península Ibérica (siglos VII-XII)”. Talia dixit 4 (2009), pp. 113-190, p. 139).

27. BAUTISTA, Francisco - "Listas Regias", p. 141. Para outra visão dos objectivos deste texto veja-se GOMES, Maria Joana - O rei na escrita, pp. 321-323.

28. CHRONICON Compostellanum, p. 80: "[...] Sancius primogenitus frater cum duobus fratribus singulis uicibus pugnauit et bello captos alterm, scilicet Adefonsum, Toletum, alterum uero, scilicet Garseam, Ispalim cum omnibus suis militibus in exilium abire permisit". De salientar que esta informação sobre a partida de Garcia para Sevilha será apenas retomada mais tarde pela historiografia afonsina e pós-afonsina.

29. CHRONICON Compostellanum, p. 81: "Ipse enim Adefonsus sue sororis Urrache consilio eum [Garcia] captum feria IIII idus Februarii era ICXI in carcere retrusit et usque ad mortem eum ibi tenuit".

30. CHRONICON Compostellanum, p. 81.

31. REGLERO DE LA FUENTE, Carlos - "Omnia totius regni sui monasteria: la Historia Legionensis, llamada Silense, y los monasterios de las infantas". e-Spania [em linha] 14 (2012), § 71 [Consultado a 25-02-2017]. Disponível em: http://

espania.revues.org/21775\#ftn3

32. PELAIO DE OVIEDO - Crónica del Obispo don Pelayo. Ed. Benito Sánchez Alonso, Madrid: Centro de Estudios Historicos, Imprenta de los sucesores de Hernando, 1924. Utilizo a designação Chronica Pelagiana proposta por Enrique Jerez.

33. A Chronica Pelagiana integra o conjunto de escritos compilados e redigidos por Pelaio de Oviedo de forma a promover os direitos e a autoridade da sua diocese e a que se convencionou chamar Corpus Pelagianum. Como mostrou Enrique Jerez (JEREZ, Enrique - El Chronicon Mundi de Lucas de Tui, pp. 94-95) a elaboração deste corpus tem três fases distintas. Perdida a mais antiga, temos hoje testemunhos manuscritos da Compilação A e da Compilação B. A edição da Chronica Pelagiana, elaborada por Benito Sánchez-Alonso em 1924, baseia-se na Compilação B, mas dá conta das adições integradas nesta terceira fase. Relativamente à datação, tem sido proposta a data de 1130 para a Compilação $A$ e uma datação posterior a 1153 para a Compilação $B$ (e, portanto, elaborada já depois da morte de Pelaio de Oviedo. Para uma posição diferente relativamente à datação da Compilação $B$, veja-se ALONSO, Raquel - "El rey Alfonso VI (m. 1109) en la obra del obispo Pelayo de Oviedo (m. 1153)". in Imágenes del poder en la Edad Media. Estudios in Memoriam del Prof. Dr. Fernando Galván Freile. León: Universidad de León e Instituto de estudios medievales, 2011, pp. 13-32, p. 16.

34. PELAIO DE OVIEDO - Crónica del Obispo don Pelayo, p. 79: "Post non multos uero dies uoluit capere regnum fratris sui Garseani, et per ingenium graue sine pugna captus est Garseanus rex et missus in uinculis per XX annos [...]".

35. CHRONICA Naierensis. Ed. Juan Estévez Sola. Corpus Christianorum Continuatio Medievalis ( Chronica Hispana saeculi XII, Pars II), vol. 71A. Turnhout: Brepols, 1995.

36. ESTÉVEZ SOLA, Juan - "Introducción". in Crónica Najerense. Ed. e trad. espanhola Juan A. Estévez Sola. Madrid: Akal, 2003, pp. 8-9.

37. Para os princípios políticos postulados pelo texto pode consultar-se, entre outros trabalhos: BAUTISTA, Francisco - "Sancho II y Rodrigo Campeador en la Chronica Naierensis”. e-Spania [em linha] 7 (2009), § 2 [Consultado a 20-01-2017]. Disponível em: 
http://e-spania.revues.org/18101 KLINKA, Emmanuèlle - “Chronica naiarensis: de la traición a la exaltación”. e-Spania [em linha] 7 (2009) [Consultado a 22-10-2017].

Disponível em: http://e-spania.revues.org/18934 MARTIN, Georges - "Mujeres de la Najerense". e-Spania [em linha] 7 (2009) [Consultado a 22-10-2017]. Disponível em: http:// espania.revues.org/17990

38. BAUTISTA, Francisco - "Sancho II y Rodrigo Campeador".

39. Segundo GLARE, P.G. - Oxford Latin dictionary. Oxford: Oxford University Press, 1968, p. 570 , “dolus" pode ter o sentido de uma armadilha concreta ou também, de forma mais abrangente, traição ou embuste. Para NIERMEYER, J.F. - Mediae latinitatis lexicon minus. 2 vols. Leiden: Brill, 1975, p. 347, “dolus” significa engano.

40. CHRONICA Naierensis, p. 172: "Set cum Garsias illi apud Sanctum Yreneum doli nescius et obsequiosus occurreret, mox captus et uinculis mancipatus Castellam per extra caminum ducitur et in graui custodia per XXIIII annos usque ad obitum detinetur".

41. BAUTISTA, Francisco - Sancho II y Rodrigo Campeador, § 10-11.

42. GLARE, P. G. - Oxford Latin Dictionary, p. 1221.

43. NIERMEYER, J.F. - Mediae Latinitatis, pp. 729-730. O adjectivo obsequiosus não vem listado.

44. Veja-se nota 56.

45. O emprego de ingenium e de fraus com o sentido de "engano" também ocorre na Historia Roderici, outra crónica redigida no século XII, sinal de que o uso de tais lexemas como sinónimos não se limitava ao caso que temos vindo a relatar. Ver PÉREZ RODRÍGUEZ, Estella - "La Historia Roderici en su aspecto léxico: Estudio comparativo en relación con la Chronica Adefonsi Imperatoris y las crónicas hispanolatinas anteriores al siglo XIII". e-Spania [em linha] 15 (2013), § 66 [Consultado a 25-02-2017]. Disponível em: http://e-spania.revues.org/22341

46. LUCAS DE TUI - Chronicon Mundi. Ed. Emma Falque. Corpus Christianorum Continuatio Medievalis, vol. 74. Turnholt: Brepols, 2003. Apesar de uma abundante tradição manuscrita (existem actualmente dezanove manuscritos (dois truncados), sendo o mais antigo do século XIII e o mais recente do século XVII) teve parca fortuna editorial: depois da edição realizada pelo padre Mariana para a obra de Andreas Schott no século XVII (mais concretamente em 1608), foi só no final do século XX que o texto de Lucas de Tui conheceu nova edição e estudo, tendo sido o tema da tese de doutoramento de Olga Valdés García. Já no século XXI, elaborada por Emma Falque e publicada na colecção do Corpus Christianorum.

47. Esta datação é proposta por FALQUE, Emma - “Introduction”. in LUCAS DE TUI Chronicon Mundi, Ed. Emma Falque. Corpus Christianorum Continuatio Medievalis, vol. 74, Turholt: Brepols, 2003, p. xix. JEREZ, Enrique - El Chronicon Mundi, pp. 351-354, propõe como terminus ante quem o ano de 1238.

48. Para os aspectos biográficos de Lucas de Tui ver sobretudo: JEREZ, Enrique - El Chronicon Mundi, pp. 180-182; FALQUE, Emma - "Introduction", pp. vii-xii e LINEHAN, Peter - "Fechas y sospechas sobre Lucas de Tuy". Anuario de Estudios Medievales 32/1 (2002), pp. 18-38. Mais recentemente HENRIET, Patrick - “Lucas de Tuy”. in THOMAS, D.; MALLETT, A. (dir.) - Christian-Muslim Relations. A Bibliographical History, 4: 1200-1350. Leyden/New-York: Brill, 2012, pp. 271-279.

49. Sobre estas obras ver JEREZ, Enrique - El Chronicon, pp. 182-183 e respectivas notas. 50. LUCAS DE TUI - Chronicon Mundi, Praef., p. 4): “Astrictus preceptis gloriosissimae ac prudentissimae Hispaniarum reginae dominae Berengariae, [...] hanc praemisi praefactionem ut prima fronte voluminis discant Principes praeclaro negotio sanguine generosi non minus sapienter 
et clementer quam in manu valida regna sibi subdita gubernare". Sobre os propósitos didáticos do Chronicon Mundi, ver MARTIN, George - Les Juges, p. 233 e LINEHAN, Peter - "De Lucas de Tui a Alfonso X". in FERNÁNDEZ-ORDÓNEZ, Inés (org.) - Alfonso X el sabio y la Cronicas de España. Valladolid: Universidad de Valladolid, 2000, pp. 19-36, pp. 23-24.

51. O estudo mais complete e rigoroso das fontes historiográficas usadas por Lucas de Tui é a tese de doutoramento de Enrique Jerez, já citada. Para as citações e referências bíblicas e patrísticas veja-se a edição do texto preparada por Emma Falque. Sobre a relação entre o Chronicon Mundi e outras obras do Tudense veja-se HENRIET, Patrick - “ Sanctissima patria. Points communs entre les trois œuvres de Lucas". in HENRIET, Patrick (dir.) - Actes du colloque: Chroniqueur, hagiographe, théologien. Lucas de Túy (†1249) dans ses œuvres, Sorbonne-Collège d'Espagne, 10 décembre 1999). Cahiers de linguistique et de civilisation hispaniques médiévales 24 (2001), pp. 249-278; REILLY, Bernard - "Sources of the fourth book of Lucas of Túy's Chronicon mundi”. Classical Folia 30 (1976), pp. 127-137, considera que algumas partes apresentam semelhanças linguísticas com a Chronica Naierensis, e com a Historia Regum Castellae, mas atribui essa proximidade ao uso de fontes comuns, hoje desconhecidas.

52. Para a técnica compositiva de Lucas de Tui ver JEREZ, Enrique - El Chronicon Mundi, pp. 164-179.

53. Veja-se acima, pp. 9-10.

54. JEREZ, Enrique - El Chronicon Mundi, p. 145.

55. Veja-se acima, p. 13.

56. LUCAS DE TUI - Chronicon Mundi, p. 298: "Rex etiam Sancius fratrem suum Garsiam iuniorem cepit, et ut sibi esset subditus, acceptis obsidibus et sacramento eum dimisit". Podemos ver aqui talvez uma reinterpretação feudo-vassálica de uma forma mais antiga de partilha do poder entre irmãos, habitual em Navarra e que preconizava a primazia do primogénito sobre os outros irmãos. Se considerarmos o episódio da partição dos reinos sob esse prisma, então a acção militar de Sancho contra os seus irmãos pode significar uma represália justa contra um possível incumprimento por parte de Afonso e de Garcia das suas obrigações para com o irmão mais velho. Veja-se sobre este tema GOMES, Maria Joana - O rei na escrita, p. 286, n. 1034.

57. LUCAS DE TUI - Chronicon Mundi, pp. 298-301.

58. LUCAS DE TUI - Chronicon Mundi, pp. 310-302: "Rex uero Garsias frater eius, ut uidit sui regni Gallecos ad regem Adefonsum prosperare, iratus est ualde, et cepit bellum inferre regi Adefonso fratri suo. Adefonsus autem habito consilio sororis Urrace et Petri Ansuri misit nuncius ut eum tractare de pacem. Garseanus autem ut nuncios fratris uidit, et erat simplicis ingenii, uenit ad regem Adefonsum nulla fide de securitate".

59. Segundo GLARE, P. G. - Oxford Latin Dictionary, p. 1765, o adjectivo simplex tem um sentido contraditório no que respeita à natureza humana: tanto pode querer dizer puro, bem-intencionado ou ingénuo, como pode uma conotação mais marcadamente negativa como ignorante ou pouco inteligente (a obra de J.F. Niermeyer não refere este adjectivo). O duplo sentido do étimo é palpável na construção historiográfica da figura de Carlos III, rei da França Ocidental entre 898 e 922, cognominado o Simples. De acordo com Auguste Eckel, esse cognome foi-lhe atribuído por cronistas posteriores à sua morte, sendo que a conotação negativa de simplex surge já no século XI, numa crónica redigida no mosteiro beneditino de Montier-en-Der: "Tempora hujusmodi infelicitatis impediebantur regimine Karoli junioris, qui Simplex ferebatur nomine, non tam innocentia quam ignavia omnis rei civilis et militaris" (ECKEL, Auguste - Charles le Simple. Paris: Éd. Bouillon, 1899, pp. 142-143). Pode, portanto, assumir-se que Lucas de Tui pode usar o epíteto simplex ingenium num sentido 
negativo. Outro dado interessante a ter em conta é semelhança entre a história e prisão de Carlos, o Simples, com a versão do Toledano da prisão de Garcia. Abordaremos este aspecto um pouco mais adiante. Por outro lado, Lucas de Tui conhecia a obra de Pelaio de Oviedo para quem a captura de Garcia tinha sido obtida por via de um graue ingenium, no sentido de artifício ou estratagema. É possível que Lucas de Tui tenha interpretado ingenium, não no sentido de dolus, mas antes com o sentido de inteligência ou disposição. 60. LINEHAN, Peter - "De Lucas de Tuy", p. 22.

61. Sobre a influência de Isidoro de Sevilha em Lucas de Tui, veja-se HENRIET, Patrick - “ Sanctissima patria, pp. 257-264; FALQUE, Emma - "En torno a la figura de Isidoro en el s. XIII: Lucas de Tuy". Antiquité Tardive 23 (2015), pp. 249-260.

62. Lucas de Tui elenca cinco requisitos necessários ao bom governo: Reconhecer a Deus como seu rei e criador, admitir os preceitos e as palavras do catolicismo, conservar a paz do reino, guardar a justiça, e combater o inimigo (LUCAS DE TUI, Chronicon Mundi, Praef., p. 3): "Rex dicitur a regendo, quod se eta lios bene regat; cui specialius quinque sunt necessaria: primo videlicet creatorem et regem suum, Patrem et Filium et Spiritum sanctum, unum uerum Deum in unitate substancie et in trinitate personarum agnoscere; secundo fidem catholicam moribus et uerbis confiteri: tercio regnum in pace omnimode conservare; quarto sine accipetione personarum unicuique iusticiam exibere; quinto uero hostes uiriliter, contemptis cunctis laboribus, expugnare".

63. LUCAS DE TUI - Chronicon Mundi, Praef., p. 8: “(...) habent mundi sapientes inter ceteros peritos sapientissimos; habent et milites strenuos inter ceteros milites mundi precipue animosos. Quorum animositas et audacia tam feruida est ut non sollum illos, uerum etiam patriam nonnunquam in periculum ducat". LUCAS DE TUI - Chronicon Mundi, Praef., pp. 8-9: "Habet etiam Yspanie princeps uiros consilii, quos natura sapientia fecit insignes; habetut dictum est, milites bellicosos, et etiam pedites agiles et animos".

64. A sapientia é uma das qualidades que possibilita o alcance dos cinco requisitos para o exercício de uma boa governação. A importância destas características vem confirmada através de citações bíblicas: "Beata terre cuius rex sapiens est et cuius principes uescuntur tempore suo", do consilium: "rex qui sedet in solio iudicii, intuitu suo dissipat omne malum" (LUCAS DE TUI - Chronicon Mundi, Praef., p. 4). Para a importância desta qualidade para Lucas de Tui (e Rodrigo de Rada) ver RODRÍGUEZ DE LA PEÑA, Manuel Alejandro - "Rex institutor scholarum: la dimensión sapiencial de la realeza en la cronística de León-Castilla y los orígenes de la Universidad de Palencia". Hispania Sacra 126 (2010), pp. 491-512, sobretudo pp. 493-497.

65. O sentimento anti-nobiliárquico em Lucas de Tui foi notado por MARTIN, George - Les Juges, pp. 205-206 e 225-226, e denotado também por outros lexemas que pertencem ao campo semântico da violência, como a ira (ira), a ferocidade (ferocitas), belicosidade ( bellicosus), a avareza (avaritia) e a cupidez (cupiditas).

66. LUCAS DE TUI - Chronicon Mundi, p. 302: “Tam sapienter rex Adefonsus regni gessit gubernacular, ut omnes potestates, nobiles diuites uel pauperes qui erant in regno, erant in quiete, ita quod non auderet unus contra alterum litem mouere nec aliquid mali facere". Lucas de Tui prossegue na descrição do retrato de Afonso VI utilizando informações retiradas da Chronica Pelagiana. No entanto, esta referência a sapiência parece ser da autoria do próprio, aplicando assim ao conquistador de Toledo algumas das qualidades que atribui a Afonso VIII, o rei-modelo por excelência.

67. De acordo com Gregório Magno, há dois tipos de reis que resvalam para a má governação. Um é o tirano, que se caracteriza por violar deliberadamente preceitos da justiça, da moral e da religião (iniquus). O outro é o rei “inútil” que exibe características 
como a letargia, negligência, inépcia e ignorância. No século IX, é a incapacidade mental ou física, a má-gestão administrativa ou a decadência moral que estão associadas à figura do rex inutilis (PETERS, Edward - The shadow king, p. 43, p. 72).

68. RODRIGO XIMÉNEZ DE RADA - De rebus hispaniae sive historia gothica. Ed. Juan Valverde. Corpus Christianorum Continuatio Mediaevalis, vol. 72, Turnhout: Brepols, 1989.

69. Esta crónica relata os acontecimentos ocorridos entre o povoamento (mítico) da Espanha e a conquista de Córdova por Fernando III (RODRIGO XIMÉNEZ DE RADA - De Rebus Hispaniae, Prol., p. 7: “(...) a tempore Iaphet Noe filii usque ad tempus uestrum, gloriossissime rex Fernande (...)”).

70. Ao contrário do que sucede com Lucas de Tui, o percurso biográfico de Rodrigo de Rada é bem conhecido. Vários autores traçaram a biografia do arcebispo toledano de maneira mais ou menos elaborada, como é o caso de J. Gorosterratzu, Hilda Grassotti, María Desamparados Cabanes Pecourt, Peter Linehan e Juan Valverde. Mais recentemente, MARTIN, Georges - Les Juges, pp. 255-258). 0 próprio epitáfio de Rodrigo de Rada descreve assim a sua vida: "Mater Navarra, nutrix Castella, Parisium studium, toletum sedes, mors rhodanus, orta mauseolum calum requies, nomen Rodericus".

71. VALVERDE, Juan - "Introducción". in RODRIGO XIMÉNEZ DE RADA - De Rebus Hispaniae, ed. Juan Valverde, 1989, pp. xxxv-xxxix. O autor da edição crítica não consegue saber com certeza se o autor utilizou ou não a Historia Legionensis, mas garante Rodrigo de Rada conheceu certamente a Chronica Naierensis e a Chronica Pelagiana. Em casos pontuais, como por exemplo assuntos que se relacionam mais de perto com a sua diocese, terá também recorrido a materiais conservados no arquivo da catedral de Toledo. Ver também LINEHAN, Peter - "De Lucas de Tui".

72. LINEHAN, Peter - "De Lucas de Tui", pp. 21-22.

73. RODRIGO XIMÉNEZ DE RADA - De Rebus Hispaniae, Praef., p. 5: "Fidelitas antiquitatis, antiquas fidelitatis primeuorum doctrix et genitrix posterorum credidit actibus minorari si sibi soli se genitam reputaret".

74. Tendo esse objectivo em conta, tem uma atitude conciliatória para com os outros grupos sociais, em especial a aristocracia. MARTIN, Georges - "Nobleza y realeza en el De rebus Hispaniae (Libros 4 a 9)". in MOLINIE, Annie; ZIMMERMANN, Marie-Claire; RALLE, Michel (pres.) - Hommage à Carlos Serrano. Paris: Éditions hispaniques, 2 vols., 2005, pp. 1-23, pp. 1-2.

75. MARTIN, Georges, Les Juges, p. 267.

76. RODRIGO XIMÉNEZ DE RADA - De Rebus Hispaniae, Praef., pp. 5-6: “[...] gesta etiam principium quorum alios ignauia fecit uiles, alios sapientia, strenuitas, larguitas et iustitia futuris seculis comendauit". Ver também a propósito deste assunto: MARTIN, Georges - Les Juges, pp. 262-263.

77. MARTIN, George - Les juges, p. 262; MARTIN, Georges - "Nobleza y realeza", pp. 9-12.

78. MARTIN, George - Les juges, p. 263-267; MARTIN, Georges - "Nobleza y realeza”, pp. 12-21.

79. Veja-se acima, p. 20.

80. RODRIGO XIMÉNEZ DE RADA - De Rebus Hispaniae, Liber iv, cap. xviii, p. 198: "Et cum rex Sancius circa huiusmodi moraretur, rex Garcias in suos tirannide grasabatur (...)".

81. RODRIGO XIMÉNEZ DE RADA - De Rebus Hispaniae, Liber IV, cap. xviii, p. 198: "Habebat autem quendam vernulum causa familiaris secreti plus debito sibi carum, cuius delationibus contra milites et barones aures credulas adhibebat; et licet sepius supplicassent ut a se predictum vernulum removeret, discessum eius nullatenus voluit sustinere". O episódio apresenta alguns pontos de contacto com a estória contada por alguns analistas e cronistas francos para 
justificar a rebelião dos barones da França Ocidental contra Carlos III, o simples. Este rei cumula de bens indevidos um conselheiro chamado Hagano, um acto que os aristocratas contestam e consideram motivo suficiente para uma rebelião. Mais tarde, Carlos III acaba por ser deposto e passa o resto da vida encarcerado num castelo (Ver sobre este assunto ECKEL, Auguste - Charles le Simple, pp. 107-111, e também GEARY, Patrick - Phantoms of Remeberance: memory and oblivion at the end of the first millenium. Princeton: Princeton University Press, pp. 147-153.

82. RODRIGO XIMÉNEZ DE RADA - De Rebus Hispaniae, Liber IV, cap. xviii, p. 198: “Et ipsi reputantes dedecus et iacturam quia eius delationibus ledebantur, delatorem in eius presentia occiderunt (...) In cuius morte se lesum reputans et confusum, illatum dedecus sepe obiciens omnes suos cepit affligere indistincte, districte cominans se indignationi sue nullem terminum positurum. Sui autem minarum pericula pauescentes et illatum dedecus recolentes ab eius dominio, prout poterant, discedebant".

83. RODRIGO XIMÉNEZ DE RADA - De Rebus Hispaniae, Liber IV, cap. Xvii, p. 198: “(..) rex Garsias in suos tirannide grassabatur et villis ab omnibus et a suis etiam habebatur et contra fratrem bella, licet segniter, intemptabat".

84. PETERS, Edward - The Shadow king, p. 103.

85. Em flagrante oposição com a descrição de Afonso VI, onde nos é dito que o rei age com cada um conforme as suas necessidades (RODRIGO XIMÉNEZ DE RADA - De Rebus Hispaniae, Liber IV, cap. xxi, p. 202).

86. PETERS, Edward - The Shadow King, p. 42.

87. MARTIN, George - "Nobleza y realeza”, p. 3: “(...) amenazas de deposición blandidas por los "magnates" contra Alfonso el Casto que está dispuesto a legar el reino de Oviedo a Carlomagno; ejecución, por el "senatus", de un Fruela Vermúdez que se comporta en tirano; asesinato del infante García por los nobles a quienes su padre, el conde Sancho, expulsó “indignanter" de Castilla; derrota y muerte en Atapuerca de un García III de Navarra que no supo ganarse el "animus" de los suyos; $y$, al morir sin descendencia Alfonso el Batallador, apartamiento del trono por los "nobiles" aragoneses del soberbio Pedro Atarés en beneficio de Ramiro el Monje".

\section{RESUMOS}

Garcia, filho mais novo de Fernando I (1038-1065) e de Sancha de Leão (1038-1067), foi contemplado com o reino da Galiza na divisão dos reinos promovida pelo pai. Ao fim de cinco anos de reinado, em 1071, foi preso pelo seu irmão Afonso, rei de Leão, que se torna rei da Galiza. Garcia passa o resto da sua vida encarcerado, acabando por morrer na prisão em 1090. A prisão e deposição de Garcia foram assuntos abundantemente revisitados pelas crónicas leonesas e castelhanas medievais desde o século XII. Contudo, é sobretudo no século XIII que os cronistas ibéricos começam a tecer justificações mais sólidas para os eventos ocorridos em torno desta transmissão de poder anómala. Este artigo pretende analisar os argumentos evocados pelos cronistas do século XII de forma a justificar a deposição de Garcia da Galiza, para depois avançar para o estudo do mesmo tema nas mais importantes crónicas ibéricas em latim do século XIII, o Chronicon Mundi, de Lucas de Tui, e De Rebus Hispaniae, de Rodrigo de Rada. Partindo do estudo dos 
argumentos aduzidos pelos dois cronistas tentar-se-á perceber as implicações ideológicas que a construção discursiva deste episódio tem no sistema de valores políticos que caracteriza os textos mencionados.

Garcia, the youngest son of Ferdinand of Castile (1038-1065) and Sancha of León (1038-1067), was given the kingdom of Galicia by his parents, when they splited their kingdom by their sons. Five years into his reign, he was captured and imprisoned by one of his elder brothers, Alfonso, king of León, who becomes king of Galicia in its brother's place. The former king spent the rest of his life in prison until his death in 1090. The circumstances which led to Garcia's arrest and captivity were frequently debated among the $12^{\text {th }}$ medieval Iberian Latin historiographers. However, it is in the $13^{\text {th }}$ century that historians elaborate more solid justifications to make sense, not only Garcia's fate but also the anoumalous power transmission that took place. This paper analyses the arguments brought up by the works of several $12^{\text {th }}$ and $13^{\text {th }}$ century historiographers of western Iberia - conceeding special attention to Lucas de Tuy's Chronicon Mundi and Rodrigo de Rada's De rebus Hispaniae - to justify the fall of Garcia of Galicia. It aims at understanding the relation between the discursive mutations of this episode and the writers' political and ideological conceptions.

ÍNDICE

Keywords: Chronicon Mundi, De rebus hispaniae, Garcia of Galicia, medieval kingship, 13th century

Palavras-chave: Chronicon Mundi, De rebus hispaniae, Garcia da Galiza, realeza medieval, século XIII

\section{AUTOR}

\section{MARIA JOANA GOMES}

Universidade do Porto, Instituto de Filosofia / SMELPS - Seminário Medieval de Literatura, Pensamento e Sociedade, 4150-654, Porto, Portugal yseutz@gmail.com 